\title{
Some New Derivatives of Organozirconium(IV) With Pyridinedicarboxylic Acids
}

\author{
${ }^{*}$ SATISH C. DIXIT and ${ }^{* *}$ ROHIT K. SINGH \\ *Deptt. of Chemistry, D.B.S. College, Kanpur-208006, India \\ ${ }^{* *}$ Deptt. of Chemistry, Pt. J.L.N. College, Banda (U.P.), India \\ satishdixit1@gmail.com
}

Received 9 September 2011; Accepted 15 October 2011

\begin{abstract}
Reactions of dichlorobis(cyclopentadienyl)zirconium(IV) with pyridinedicarboxylic acids viz. quinolinic acids $\left(\mathrm{QAH}_{2}\right)$, 2,4-pyridine dicarboxylic acid $\left(\mathrm{PAH}_{2}\right)$, isocinchomeronic acid $\left(\mathrm{IAH}_{2}\right)$, cinchomeronic acid $\left(\mathrm{CAH}_{2}\right)$ and dinicotinic acid $\left(\mathrm{DAH}_{2}\right)$ were carried out in different stoichiometric ratios. Complexes of the type $\mathrm{Cp}_{2} \mathrm{Zr}(\mathrm{QAH}) \mathrm{Cl}, \mathrm{Cp}_{2} \mathrm{Zr}(\mathrm{QAH})_{2}$, $\mathrm{Cp}_{2} \mathrm{Zr}(\mathrm{PAH}) \mathrm{Cl}, \mathrm{Cp}_{2} \mathrm{Zr}(\mathrm{PAH})_{2}, \mathrm{Cp}_{2} \mathrm{Zr}(\mathrm{IAH}) \mathrm{Cl}, \mathrm{Cp}_{2} \mathrm{Zr}(\mathrm{IAH})_{2}, \mathrm{Cp}_{2} \mathrm{Zr}(\mathrm{CAH}) \mathrm{Cl}$, $\mathrm{Cp}_{2} \mathrm{Zr}(\mathrm{CAH})_{2}, \mathrm{Cp}_{2} \mathrm{Zr}(\mathrm{DAH}) \mathrm{Cl}$ and $\mathrm{Cp}_{2} \mathrm{Zr}(\mathrm{DAH})_{2}$ were obtained. These new complexes were characterized on the basis of their elemental analyses, electrical conductance, magnetic moment and spectral data.
\end{abstract}

Keywords: $\mathrm{Cp}_{2} \mathrm{ZrCl}_{2}$, Pyridinedicarboxylic Acids, Synthesis, Characterization, Complexes.

\section{Introduction}

Despite the discovery of cis-platin in the treatment of cancer ${ }^{1-4}$, there has been a considerable exploration on the antitumoral activity of the other transition metal complexes. Recently, much attention has been paid on the titanium based complexes, which could have significant potential effect against solid tumour. $\mathrm{Cp}_{2} \mathrm{TiCl}_{2}$ reached phase II clinical trials, but its efficiency in patients with metastatic renal cell carcinoma ${ }^{5}$ or metastatic breast cancer ${ }^{6}$ was too low. Zirconocene dichloride is a poor antitumour agent ${ }^{7}$. Metallocenes and metallocene dichlorides have also been shown to effect the metabolism of certain drugs. Paralysis induced in rats by the drug Zaxozalamine (2-amino-5-chlorobenzoxazole) was prolonged by the injection of $\mathrm{Cp}_{2} \mathrm{TiCl}_{2}, \mathrm{Cp}_{2} \mathrm{ZrCl}_{2}$ and $\mathrm{Cp}_{2} \mathrm{HfCl}_{2}{ }^{8}$. Pyridinedicarboxylic acids have been found on the basis of the reported $\mathrm{x}$-ray molecular structures to be interesting and versatile ligands ${ }^{9}$. A very important characteristic of pyridinedicarboxylic acids is their diverse biological activity ${ }^{10,11}$. 2,4- and 2,5-Pyridinedicarboxylic acids are found to inhibit the enzyme GA $2 \beta$ - hydroxylase and its mechanistically related enzyme proline 4 - hydroxylase ${ }^{12}$. Sengupta et al. ${ }^{13}$ synthesized the ruthenium(II) complexes of 2,3-, 2,4 - and 2,5-pyridinedicarboxylic acids and found interesting results. More recently, Chen et al. ${ }^{14}$ synthesized many new heterometallic complexes of 2,3-pyridinedicarboxylic acids.

A survey of the literature reveals that no work has been carried out on the reactions of $\mathrm{Cp}_{2} \mathrm{ZrCl}_{2}$ with quinolinic acid, 2,4-pyridinedicarboxylic acid, isocinchomeronic acid, cinchomeronic acid and dinicotinic acid. It was, therefore, considered of interest to carry 
out the reactions of dichlorobis(cyclopentadienyl)zirconium(IV) with quinolinic acid, 2,4-pyridine dicarboxylic acid, isocinchomeronic acid, cinchomeronic acid and dinicotinic acid. The structure of the ligands used is given below.<smiles>O=C(O)c1cccnc1C(=O)O</smiles>

2, 3-pyridine dicarboxylic acid (Quinolinic acid)

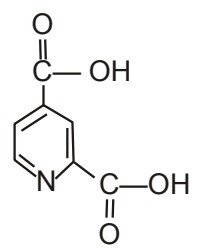

2, 4-pyridine dicarboxylic acid<smiles>O=C(O)c1ccc(C(=O)O)nc1</smiles>

2, 5-pyridine dicarboxylic acid (Isocinchomeronic acid)<smiles>O=Cc1ccncc1C(=O)O</smiles>

3, 4-pyridine dicarboxylic acid (Cinchomeronic acid)<smiles>O=C(O)c1cncc(C(=O)O)c1</smiles>

3, 5-pyridine dicarboxylic acid (Dinicotinic acid)

\section{Experimental}

THF(Ferak, Berlin, FRG) was dried according to the method described ${ }^{15}$. Triethylamine and $n$-hexane were dried by the standard method ${ }^{16}$. Dichlorobis (cyclopentadienyl) zirconium(IV) (Aldrich), quinolinic acid (Aldrich), 2,4-pyridinedicarboxylic acid (Aldrich), isocinchomeronic acid (Aldrich), cinchomeronic acid (Aldrich) and dinicotinic acid (Aldrich) were used as supplied. Stringent precautions were taken to exclude the moisture from the system. The reactions were carried out under dry nitrogen with system well protected from atmospheric nitrogen by means of calcium chloride guard tubes.

Analysis for carbon, hydrogen and nitrogen was carried out at the Central Micro Analytical Laboratory of IIT, Kanpur. Zirconium was estimated gravimetrically as $\mathrm{ZrO}_{2}$. Chlorine was determined as $\mathrm{AgCl}$. The IR spectra were recorded on a Perkin -Elmer 1710 Infrared Fourier Transform spectrometer in the region $400-4000 \mathrm{~cm}^{-1}$ in $\mathrm{KBr}$ pellets. The electronic spectra of the complexes in chloroform were recorded on a Shimadzu UV-260 spectrophotometer.

\section{Preparation of complexes}

A general procedure was followed to synthesize the complexes of $\mathrm{Cp}_{2} \mathrm{ZrCl}_{2}$ with quinolinic acid, 2,4-pyridine dicarboxylic acid, isocinchomeronic acid, cinchomeronic acid and dinicotinic acid which involved the mixing of the reactants in anhydrous tetrahydrofuran at room temperature in the presence of triethylamine. The reaction mixture was stirred for $\sim 32-42$ hours. The precipitated $\mathrm{Et}_{3} \mathrm{~N} . \mathrm{HCl}$ was filtered off and the solvent was removed under reduced pressure. The product so obtained was recrystallized from a $n$-hexane/ THF mixture. The relevant details of the preparative method used and the complexes obtained are summarized in Table 1. The analytical data of these complexes are tabulated in Table 2. 
Table 1. Reactions of $\mathrm{Cp}_{2} \mathrm{Zr} \mathrm{Cl}_{2}$ with Pyridinedicarboxylic Acids.

\begin{tabular}{|c|c|c|c|c|c|c|}
\hline \multicolumn{3}{|c|}{ Reactants, $\mathrm{g}$} & \multirow{2}{*}{$\begin{array}{l}\text { Molar } \\
\text { Ratio }\end{array}$} & \multirow{2}{*}{$\begin{array}{l}\text { Stirring } \\
\text { Time, h }\end{array}$} & \multirow{2}{*}{ product } & \multirow{2}{*}{$\begin{array}{c}\text { Colour } \\
\text { Decompo.temp, }{ }^{\circ} \mathrm{C}\end{array}$} \\
\hline $\mathrm{Cp}_{2} \mathrm{ZrCl}_{2}$ & Acid & $\mathrm{Et}_{3} \mathrm{~N}$ & & & & \\
\hline 0.82 & $\begin{array}{l}\mathrm{QAH}_{2} \\
0.46\end{array}$ & 0.28 & $1: 1: 1$ & 32 & $\left(\mathrm{C}_{5} \mathrm{H}_{5}\right)_{2} \mathrm{Zr}(\mathrm{QAH}) \mathrm{Cl}$ & $\begin{array}{c}\text { Brown } \\
110\end{array}$ \\
\hline 0.78 & $\begin{array}{c}\mathrm{QAH}_{2} \\
1.14\end{array}$ & 0.54 & $1: 2: 2$ & 35 & $\left(\mathrm{C}_{5} \mathrm{H}_{5}\right)_{2} \mathrm{Zr}(\mathrm{QAH})_{2}$ & $\begin{array}{c}\text { Brown } \\
115\end{array}$ \\
\hline 0.84 & $\begin{array}{c}\mathrm{PAH}_{2} \\
0.53\end{array}$ & 0.29 & $1: 1: 1$ & 36 & $\left(\mathrm{C}_{5} \mathrm{H}_{5}\right)_{2} \mathrm{Zr}(\mathrm{PAH}) \mathrm{Cl}$ & $\begin{array}{c}\text { Dark Brown } \\
105\end{array}$ \\
\hline 0.69 & $\begin{array}{c}\mathrm{PAH}_{2} \\
1.01\end{array}$ & 0.48 & $1: 2: 2$ & 35 & $\left(\mathrm{C}_{5} \mathrm{H}_{5}\right)_{2} \mathrm{Zr}(\mathrm{PAH})_{2}$ & $\begin{array}{c}\text { Brown } \\
\text { 120(M.P.) }\end{array}$ \\
\hline 0.72 & $\begin{array}{c}\mathrm{IAH}_{2} \\
0.50\end{array}$ & 0.25 & $1: 1: 1$ & 38 & $\left(\mathrm{C}_{5} \mathrm{H}_{5}\right)_{2} \mathrm{Zr}(\mathrm{IAH}) \mathrm{Cl}$ & $\begin{array}{c}\text { Dark Brown } \\
115\end{array}$ \\
\hline 0.65 & $\begin{array}{l}\mathrm{IAH}_{2} \\
0.95\end{array}$ & 0.45 & $1: 2: 2$ & 39 & $\left(\mathrm{C}_{5} \mathrm{H}_{5}\right)_{2} \mathrm{Zr}(\mathrm{IAH})_{2}$ & $\begin{array}{c}\text { Light Brown } \\
108\end{array}$ \\
\hline 0.82 & $\begin{array}{c}\mathrm{CAH}_{2} \\
0.54\end{array}$ & 0.28 & $1: 1: 1$ & 40 & $\left(\mathrm{C}_{5} \mathrm{H}_{5}\right)_{2} \mathrm{Zr}(\mathrm{CAH}) \mathrm{Cl}$ & $\begin{array}{c}\text { Brown } \\
118\end{array}$ \\
\hline 0.69 & $\begin{array}{c}\mathrm{CAH}_{2} \\
1.11\end{array}$ & 0.48 & $1: 2: 2$ & 39 & $\left(\mathrm{C}_{5} \mathrm{H}_{5}\right)_{2} \mathrm{Zr}(\mathrm{CAH})_{2}$ & $\begin{array}{c}\text { Brown } \\
125\end{array}$ \\
\hline 0.84 & $\begin{array}{c}\mathrm{DAH}_{2} \\
0.50\end{array}$ & 0.29 & $1: 1: 1$ & 40 & $\left(\mathrm{C}_{5} \mathrm{H}_{5}\right)_{2} \mathrm{Zr}(\mathrm{DAH}) \mathrm{Cl}$ & $\begin{array}{c}\text { Dark Brown } \\
105\end{array}$ \\
\hline 0.78 & $\begin{array}{c}\mathrm{DAH}_{2} \\
1.14\end{array}$ & 0.54 & $1: 2: 2$ & 42 & $\left(\mathrm{C}_{5} \mathrm{H}_{5}\right)_{2} \mathrm{Zr}(\mathrm{DAH})_{2}$ & $\begin{array}{c}\text { Brown } \\
118\end{array}$ \\
\hline
\end{tabular}

where $\mathrm{QAH}_{2}=$ quinolinic acid ; $\mathrm{PAH}_{2}=2,4$-pyridinedicarboxylic acid, $\mathrm{IAH}_{2}=$ isocinchomeronic acid ; $\mathrm{CAH}_{2}=$ cinchomeronic acid, $\mathrm{DAH}_{2}=$ dinicotinic acid .

Table 2. Characterization Data.

\begin{tabular}{|c|c|c|c|c|c|c|}
\hline \multirow[b]{2}{*}{ Complex } & \multicolumn{5}{|c|}{ Analysis: found (calc.), \% } & \multirow{2}{*}{ 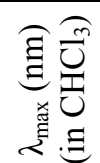 } \\
\hline & $\mathrm{Zr}$ & $\mathrm{C}$ & $\mathrm{H}$ & $\mathrm{N}$ & $\mathrm{Cl}$ & \\
\hline$\left(\mathrm{C}_{5} \mathrm{H}_{5}\right)_{2} \mathrm{Zr}(\mathrm{QAH}) \mathrm{Cl}$ & $21.6(21.58)$ & & $3.2(3.31)$ & $3.18(3.31)$ & $8.3(8.40)$ & 255.4 \\
\hline$\left(\mathrm{C}_{5} \mathrm{H}_{5}\right)_{2} \mathrm{Zr}(\mathrm{QAH})_{2}$ & $16.29(16.49)$ & $51.9(52.06)$ & $3.1(3.25)$ & & - & 260.2 \\
\hline$\left(\mathrm{C}_{5} \mathrm{H}_{5}\right)_{2} \mathrm{Zr}(\mathrm{PAH}) \mathrm{Cl}$ & $21.49(21.58)$ & & $3.2(3.31)$ & $3.1(3.31)$ & $8.29(8.40)$ & 250.0 \\
\hline$\left(\mathrm{C}_{5} \mathrm{H}_{5}\right)_{2} \mathrm{Zr}(\mathrm{PAH})_{2}$ & 16.4(16.49) & $51.8(52.06)$ & & $5.1(5.06)$ & -- & 252.2 \\
\hline$\left(\mathrm{C}_{5} \mathrm{H}_{5}\right)_{2} \mathrm{Zr}(\mathrm{IAH}) \mathrm{Cl}$ & $21.7(21.58)$ & $48.1(48.26)$ & & & $8.32(8.40)$ & 270.2 \\
\hline$\left(\mathrm{C}_{5} \mathrm{H}_{5}\right)_{2} \mathrm{Zr}(\mathrm{IAH})_{2}$ & $16.51(16.49)$ & & $3.1(3.25)$ & $5.01(5.06$ & -- & 265.4 \\
\hline$\left(\mathrm{C}_{5} \mathrm{H}_{5}\right)_{2} \mathrm{Zr}(\mathrm{CAH}) \mathrm{Cl}$ & $21.39(21.58)$ & $47.9(48.26)$ & & & $8.28(8.40)$ & 272.4 \\
\hline$\left(\mathrm{C}_{5} \mathrm{H}_{5}\right)_{2} \mathrm{Zr}(\mathrm{CAH})_{2}$ & $16.4(16.49)$ & & $3.05(3.25)$ & $5.1(5.06)$ & -- & 270.2 \\
\hline$\left(\mathrm{C}_{5} \mathrm{H}_{5}\right)_{2} \mathrm{Zr}(\mathrm{DAH}) \mathrm{Cl}$ & $21.6(21.58)$ & $47.8(48.26)$ & & & $8.3(8.40)$ & 260.4 \\
\hline$\left(\mathrm{C}_{5} \mathrm{H}_{5}\right)_{2} \mathrm{Zr}(\mathrm{DAH})_{2}$ & $16.42(16.49)$ & $51.1(52.06)$ & $3.1(3.25)$ & & -- & 258.6 \\
\hline
\end{tabular}

\section{Results and Discussion}

Reactions of $\mathrm{Cp}_{2} \mathrm{ZrCl}_{2}$ with different pyridine dicarboxylic acids viz. quinolinic acid, 2,4-pyridine dicarboxylic acid, isocinchomeronic acid, cinchomeronic acid and dinicotinic acid in 1:1 and 1:2 molar ratios in anhydrous THF in the presence of triethylamine at room temperature may be represented by the following general equation: 


$$
\begin{aligned}
& \mathrm{Cp}_{2} \mathrm{ZrCl}_{2}+\mathrm{LH}+\mathrm{Et}_{3} \mathrm{~N} \text { - } \stackrel{\text { THF }}{\text { Room temp. }} \text { C } \mathrm{Cp}_{2} \mathrm{Zr}(\mathrm{L}) \mathrm{Cl}+\mathrm{Et}_{3} \mathrm{~N} . \mathrm{HCl}
\end{aligned}
$$

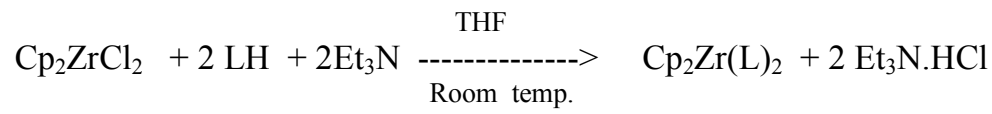

(Where $\mathrm{Cp}=$ cyclopentadienyl; $\mathrm{LH}=\mathrm{QAH}_{2}, \mathrm{PAH}_{2}, \mathrm{IAH}_{2}, \mathrm{CAH}_{2}$, or $\mathrm{DAH}_{2}$ )

All the complexes are crystalline, and extremely sensitive to hydrolysis. The complexes are soluble in tetrahydrofuran and chloroform but insoluble in n-hexane and petroleum ether. Magnetic susceptibility values at room temperature of these complexes show their diamagnetic nature. The electrical conductance measurements of these complexes in acetone showed them to be non - electrolyte.

The IR spectra of the complexes invariably exhibit the usual absorptions due to cyclopentadienyl groups at $\sim 3100 \mathrm{~cm}^{-1}[v(\mathrm{C}-\mathrm{H})], \sim 1435 \mathrm{~cm}^{-1}[v(\mathrm{C}-\mathrm{C})], \sim 1020 \mathrm{~cm}^{-1}$ $\left[\delta_{\text {i.p. }}(\mathrm{CH})\right.$ and $\sim 810 \mathrm{~cm}^{-1}\left[\delta_{\text {o.p. }}(\mathrm{CH})^{17}\right.$. The persistence of the bands of cyclopentadienyl rings in the complexes indicate that these groups are $\pi$-bonded to the metal and retain their aromatic character. The IR spectral data for the dicarboxylate complexes exhibit the presence of both the "free" carboxylic and coordinated carboxylate groups at $\sim 1700 \mathrm{~cm}^{-1}$ and $1600 \mathrm{~cm}^{-1}$ respectively. This strong evidence prove that only one of the two carboxylic acid groups is bonded to the metal. The pyridine stretch is observed at $~$ $1580 \mathrm{~cm}^{-1}$ in these newly synthesized complexes, which indicates the non - involvement of the pyridine nitrogen in the coordination. All these complexes show the ring breathing mode of the pyridine ${ }^{18,19}$ at about $\sim 998 \mathrm{~cm}^{-1}$. The absorption bands at $450 \mathrm{~cm}^{-1}$ are assigned to $v(Z r-O)$ stretching vibration ${ }^{20}$. The electronic spectra of all the complexes recorded in the chloroform show fairly intense bands between 250.2 and $272.4 \mathrm{~nm}$ which can be assigned to the charge transfer band ${ }^{21}$ and is in the accord with their $(n-1) d^{0}, n s^{0}$ electronic configuration.

On the basis of elemental analyses, spectral data, electrical conductance and magnetic susceptibility measurements, the following (I \& II ) structures can tentatively be proposed for the complexes, $\left(\mathrm{C}_{5} \mathrm{H}_{5}\right)_{2} \mathrm{Zr}(\mathrm{L}) \mathrm{Cl}$ and $\left(\mathrm{C}_{5} \mathrm{H}_{5}\right)_{2} \mathrm{Zr}(\mathrm{L})_{2}$, respectively.

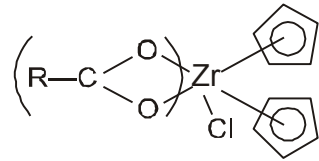

I<smiles>[R]C1O[C](c2ccccc2)[Z2](c2ccccc2)(c2ccccc2)O1</smiles>

II

where $\mathrm{L}=\mathrm{QAH}_{2}$ or $\mathrm{PAH}_{2}$ or $\mathrm{IAH}_{2}$ or $\mathrm{CAH}_{2}$ or $\mathrm{DAH}_{2}$<smiles>[R]=Cc1ccc(C)c(C(=O)O)n1</smiles>

or<smiles>Cc1ccnc(C(=O)O)c1</smiles><smiles>O=C(O)c1ccc(I)cn1</smiles>

or<smiles>Cc1ccncc1C(=O)O</smiles><smiles>Cc1cncc(C(=O)O)c1</smiles> 


\section{References}

1 Abu-Surrah A S and Kettunen M, Curr Med Chem., 2006, 13, 1337-1357.

2 Barnes KR and Lippard SJ, Met Ions Biol Syst., 2004, 42, 143-177.

3 Cepeda V, Fuertes M A, Castilla J, Alonso C, Quevedo C and Perez J M, Anti Cancer Agents Med Chem., 2007, 7, 3-18.

$4 \quad$ Yang P and Guo M, Coord Chem Rev., 1999, 189-211.

5 Lummen G, Sperling H, Luboldt H, Otto T and Rubben H, Cancer Chemother Pharmacol., 1998, 42, 415-417.

6 Kroger N, Kleeberg U R, Mross K, Edler I and Hossfeld G, Onkologie., 2000, 23, 60-62.

7 Kopf-Maier P, Wagner W and Kopf H, Cancer Chemother Pharmacol., 1981, 5, 237.

8 Buu-Hoi N P, Hien-Do-Phouc and Huynh-Trong Hieu C R, Acad Sci Ser D., 1970, 217, 270.

9 Cariati F, Naldini L, Panzanelli A, Demartin F and Manassero M, Inorg Chim Acta., 1983, 69, 117.

10 Bailey G F, Karp S and Sacks T E, J Bacteriol., 1965, 89, 98

11 Setlow B and Setlow P, Appl Environ Microbiol., 1993, 59, 640.

12 Griggs D L, Heden P, Temple Smith K E and Rademacher W, Phytochem., 1991, 30, 2513.

13 Sengupta P, Ghosh S and Mak T C W, Polyhedron, 2001, 20, 975-980.

14 Chen L, Lin X, Ying Y, Zhan Q, Hong Z, Li J, Weng N and CaiY, Inorg Chem Commun., 2009, 12, 761-765.

15 Dixit S C, Sharan R and Kapoor R N, J. Organomet Chem., 1987, 332, 135.

16 Vogel A I, A Text Book of Practical Organic Chemistry, Longman Green, London, 1948.

17 Fritz H P, Adv Organomet Chem., 1964, 262, 1.

18 Jain S C, J Sci Tech., 1970, 8A(4),169.

19 Sinha S P, Spectrochim Acta., 1964, 20, 879.

20 Sharan R, Gupta G and Kapoor R N, J Less-Common Met., 1978, 60, 171.

21 Dixit S C, Sharan R and Kapoor R N, Inorg Chim Acta, 1988, 145, 39. 


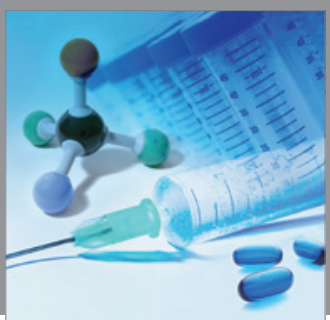

International Journal of

Medicinal Chemistry

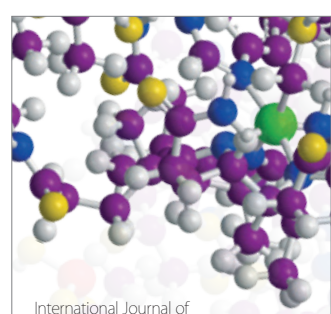

Carbohydrate Chemistry

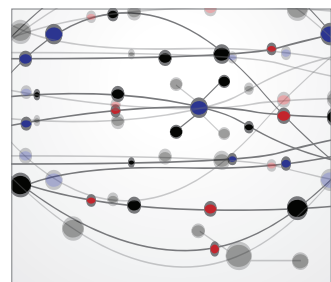

The Scientific World Journal
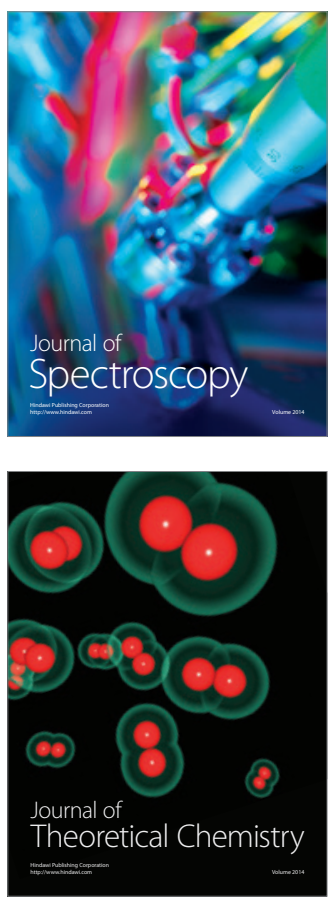
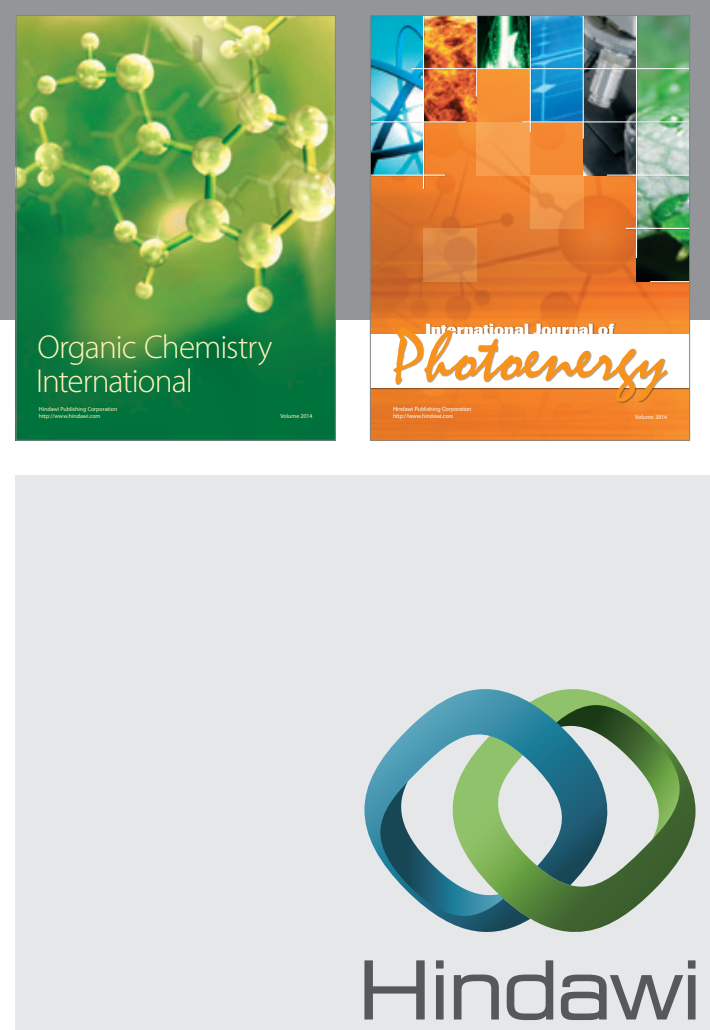

Submit your manuscripts at

http://www.hindawi.com
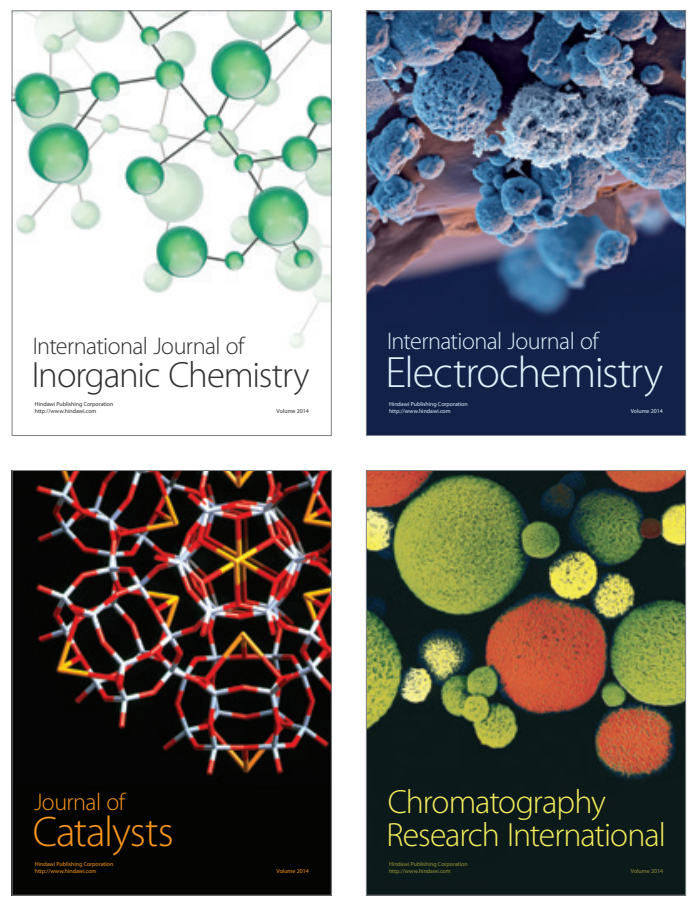
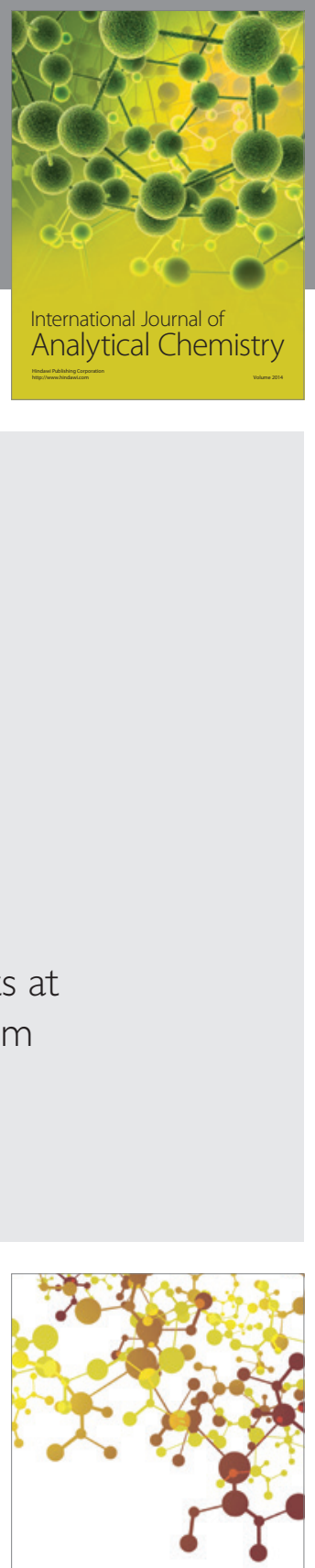

Journal of

Applied Chemistry
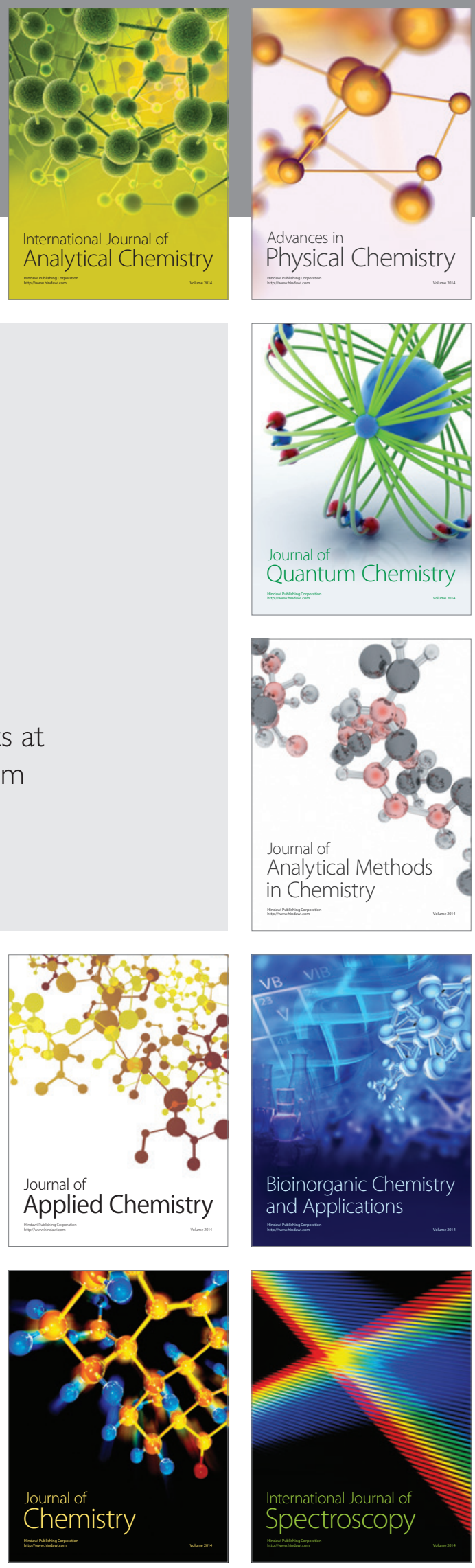